\title{
Score Mining Rents in Terms of Investment Attractiveness of Peat Mining
}

\author{
Gennady Alexandrov ${ }^{1}$, and Alexander Yablonev ${ }^{1, *}$ \\ ${ }^{1}$ Tver State Technical University, 170026, Af. Nikitin Street, 22, Tver, Russia
}

\begin{abstract}
In this article, as determinants in the system factors underlying the investment attractiveness of the peat industry is considered a rental factor, which predetermines the significant differences and peculiarities of the investment climate in the mining business and, in particular, in the sphere of peat mining. In contrast to modern studies treated the essence and role of rents in the economic mechanism, is proposed for a new approach to solving the problems of its formation. Our approach differs in that it, firstly, adequate rental relations, objectively in extractive industries, secondly, provides consensus in the interests of the owner of peat deposits and entrepreneurs, businesses in these deposits and, thus, thirdly, contributes to the creation of a favourable investment climate in the peat extraction industry. In practical terms, in accordance with the proposed approach, we have proposed specific allocation algorithm of mining rents from the profits of peat extraction enterprises.
\end{abstract}

\section{Introduction}

The relevance of the further development of peat mining in the world, and its revival in Russia, mainly due to the fact that, firstly, there is a clearly expressed the trend deteriorating geological conditions of oil and gas extraction. Secondly, with regard to the emerging ecological situation, ecological standards and regulations on pollution ambient environment are gradually tightened, the degree of which is largely conditioned by the quantity and quality of fuel burn. It should be borne in mind and the fact that, in practical terms, in the year of 2009, the EU adopted energy program, called "20:20:20", providing for the period up to 2020 year reduced electricity consumption by $20 \%$, increasing the share of renewable energy of total consumption to $20 \%$ and reduce greenhouse gas emissions $20 \%$ also [1]. Thirdly, greater significance of energy conservation issues, the solution of which is associated primarily with the use of alternative energy sources, especially taking into account the strong upward trend of increasing the prices on not renewable hydrocarbon

\footnotetext{
* Corresponding author: alvovich@mail.ru
} 
raw materials. In this regard, the peat, which is positioned as partially or even entirely renewable energy source, in macroeconomic plans may well be regarded as strategic. In particular, only in Russia around $60 \%$ of the total stock of peat on technological factors appreciated as potentially recoverable. Annual extraction in 300 million t, existing stockpiles, even without taking into account their renewability, enough for production for 102 years. Fourthly, it is equally important to use peat as a domestic fuel to meet the challenges of energy and environment (including fire) security and improve their energy efficiency. The Russian experience shows, as well as the experience of some countries, in which the peat industry in the beginning of this century has progressed significantly in its development, the peat industry has all the prerequisites to take its rightful place in the global economy [2]. Especially when you consider the fact, that in the world, about $65 \%$ of mined peat is burned to generate heat and electricity. However, it should be noted that, to date, there are discussions about whether or not, in general, to develop production of peat, to what extent and for what purpose to develop, and whether it's on economic conditions. It is therefore not surprising that in publications on this topic are invited to pay greater attention to the serial address fundamental issues of creating economically favourable conditions for the development of the peat industry [3]. As for the Russian business community, its representatives say, that they are in no hurry with their investments "to include in the peat industry is due to the fact that it is not formed the rules of the game". It should be noted that the lack of motivation and incentives for private business to invest in extractive industries - is a common problem [4].

However, formation of adequate "rules of the game" is possible only on the basis of an analysis of the investment climate and, above all, to identify the factors contributing to its attractiveness, taking into account the fact, that these factors have, in one way or another, relate to the rental relationship, folding in the mining sector and, in particular, in the field of peat extraction.

Given the size of this article, we will stop it is not at all the factors influencing the investment climate and the level of its attractiveness, but specifically only on rental factor, so much, so that in some earlier works had already been introduced to a new, so-called "matrix" approach to investment climate assessment $[5,6]$ and the peculiarities of its use including peat spheres of business.

\section{Materials and methods}

The important thing is what we would like to focus, is firstly - on the methodology for the analysis of rents and rental relations in terms of their impact on the investment attractiveness of peat mining. Secondly - on the justification copyright value-natural profit sharing method, derived from peat activities on the part of it that is in the form of a mining (natural) rents, to be withdrawal in favour of the owner of the peat deposit, and another part of it, in the form of business income, attributable to an entrepreneur, managing on this deposit. And thirdly-on the principles of formation of organizational-economic mechanism of peat mining, which combines competitive regulation and tax administration. The use of this mechanism will result in permission objective contradictions arising between the peat extraction subjects and, thus, will contribute to the improvement of the investment climate in the peat industry.

Appeal to the methodology for the analysis of economic relations in extractive activities, in general, and peat, in particular, due to significant differences in the proposed withdrawal mechanisms mining rents, proposed by investigators. Firstly, that draws attention to itself, although these proposals have some differences, but are characterized by mostly fiscal direction. This is despite the fact that fiscal approach, by definition, is 
severely restricted in carrying out motivational and incentive functions. Nevertheless, many economists are inclined to that rental nature of subsoil must be taken into account, but offered to do solely within the framework of improvement of tax administration.

With these same positions do not stand up to criticism and proposals for improving the mining tax for taxation of extraction of solid minerals, by introducing specific tax rates linked to the real financial results of mining and mineral prices on the world market [7]. Besides, it is not clear, how these rates reflect the natural quality of deposits, if real financial results of extractive enterprises depend not only on the quality of deposits. As for the dynamics of world prices, its fluctuations, as conclusively proven, in general have nothing to do with the realities of subsoil use [8]. Proposals of this kind can only strengthen the fiscal, destimulation character of tax administration. The same problems faced by many other countries, which also concluded that existing payment systems in subsoil use require reforming, based not on the change of tax administration, but on the using of rent regulation, resulting from the differentiation of deposits on natural, including miningtechnical conditions $[9,10]$.

Secondly, and most importantly, mechanisms proposed are aimed not at the general that brings together all types of extractive activities, and on the sectoral specifics of each of the extractive industries on their own special interests. This is especially true of leading productions of fuel and energy complex: oil, gas, coal, etc., which not only occupy a monopoly position on the market, but they are budget-making enterprises. It is in orientation on their, in Russia, the tax administration system was established, with a pronounced fiscal, "robbing-distribution" type, practically excepting the possibility of using the rent regulation of extractive enterprises. Inclusion in this system peat mining is a dead-end path, not making it attractive for investment. The more so that this activity is unlikely to be able to hopefully in the foreseeable future to a decent level of state support, the peculiar natural monopolies and could therefore rely mainly on private investment.

It should be noted that in developed Western economies also dominated by tax, largely fiscal, rent withdrawal methods. It is difficult to understand, and therefore, for example, in the UK and Northern Ireland corporate profit tax is complemented by another tax on petroleum extraction and extractive industries in Norway provides for taxation in two forms: special tax and general profit tax.

It seems that the current taxation practice suit all subjects of extractive activities. State is the owner of the subsoil, bearing in mind the interests of corporations, establishes a relatively moderate tax payments, which contain only the part that is created in the course of subsoil use incremental profits. And big Russian mining companies unnecessarily, according to mind many experts, a significant portion of the incremental profit reserves.

However, all members of society are entitled to the balance of interests. Attraction for entrepreneurs will depend on whether he can expect to receive a minimum normal (average) profits on invested in business capital. The State as the owner of the subsoil and the representative of the people, to meet its interests must receive that portion of profits (in the form of rent), which is due solely to the natural quality of his deposits. There is a contradiction, whose permission must be sought in the optimal combination of tax administration and rental management. And the State as the owner of the subsoil, can and must perform a dual role: to regulate process of rent withdrawing from best quality natural deposits, and administer the taxation of business income, attributable to the user of deposit, after rent paying from the gross profit.

It only remains to solve the problem of the division of profits from extractive activities on rents, that is, on the part of it that is subject to rent regulation, and the second part of entrepreneurial income, which is the base for tax administration. 


\section{Results and discussion}

In addressing the challenge many scholars lean towards, that starting point is normal (average) profits return on capital of the entrepreneur, business in the extractive industry. In other words, mining activity, including the peat industry in accordance, with the principles of inter-branch competition must ensure business entrepreneur (ceteris paribus) profit on capital, according to the same norms, which exists in other fields of activity. And rent, as, for example, for mind J. Schumpeter, is adding to the average profit thanks to cost savings, increased productivity and a higher return capital on the best lands [11]. As a result, it is proposed to calculate rent as the difference between the gross profit from the sale of the product, extracted from the depths, and the normal, average profit. As you can see, one way or another, the definition of rent proposes essentially a purely technical approach, based on the so-called residual principle in relation to mining rent. However, a more logical is a judgement (as, for example, found A. Smith) that rent relations led by the interests of the owner of the land. It is therefore understandable that preparing and signing the agreement, the landowner is seeking to leave land user only such proportion of the product which is sufficient for recovery of capital spent by them for the acquisition of production factors, and to receive regular (normal) profit on invested capital [12]. Agrees with him Karl Marx, who pointed out that no profit is the boundary of the rent and the rent is the boundary of profit [13].

In the end, if the employer conducts business with more or less efficient than the industry average, in first case he receives during the period of validity of the user agreement for more profit, and in the second, his entrepreneurial income after payment of rent less than average profit. Actually, in this action and specific mechanism of intraindustry competition in the mining production, caused by the presence of such an additional factor, as minerals, peat deposits, and, accordingly, the emerging rental relations.

So, we have two pieces created in the production of surplus product. One part of it is due to the natural quality of the deposits and is incremental surplus product and, accordingly - the substance incremental profit (or, as it is called, super-profits), that alienation takes the rent form. Another part of it caused by capital, is the substance mainly average profit, and when implemented, takes the form of entrepreneurial income of subsoil users.

Thus, the initial point in solving the problem of the division of profits from sales of produced products on the rent and entrepreneurial income and, consequently, determine the amount of rent, intended to withdraw, is targeting on the natural deposits of the worst qualities, whose exploitation does not bring incremental product and hence incremental profits (and, hence - rents). On this occasion, J.S. Mill wrote, that the final cost on worst of the land - is a certain measure of allowing to assess the amount of rents will bring all other lands. Any plot land brings so much more regular profit on the capital, how this plot gives more than the nastiest of the cropped plots [14].

The above, allows you to offer theoretically adequate approach to the definition of the mining rents as an extension product (natural form), and, as an extension of income (value form). As you can see, it combines natural and valuation estimations, while in most cases it is proposed that all calculations made on the basis of cost estimates [15]. This approach, let's call it natural-value, is based on the following principles and assumptions:

- produced products are sold at cost, when this extra income or loss occurring when selling products at market price, reflects only on the largest business income;

- the cost of the entire extracting product produced per unit area of the field, as well as additional income, adequate socio-normal, average production conditions, when this deviation from these conditions is reflected to the same extent and subject to the largest business income; 
- at worst natural conditions fields where incremental product and, as a consequence, the natural rent is not formed, the public value of the extracted product is seen as production cost, which provides an average profit to which the entrepreneur can expect;

- in the best areas of peat deposits (but with the average production conditions) formed an extension product, acquiring the shape of incremental (over medium) profit, which is the basis of natural rents and which is defined as the difference between the product of two identical amounts of capital and labour. As a result, the incremental profits - is the basis of the withdrawing part of the income in the form of land rents;

- the size of the withdrawing natural rents depends entirely on the purpose and nature of the State policy of its withdrawal. But it should not be higher than the value of incremental product resulting from the best natural conditions, and should not be to renegotiate the Treaty to "penetrate" into the entrepreneurial income, which has entrepreneur as a result of greater efficiency.

Implementation of this approach, in accordance with its logic may be presented in the form of an algorithm involving a number of consecutive actions (steps).

Step 1. Form a block of natural-value indexes of enterprises activity, businesses on the deposits that are included on the basis of the homogeneity of the natural conditions and natural quality in a certain $i$-based group when the total number of such groups $-n$. Thus, each of the groups will be represented by a block of indicators such as: area of mines (ha), gross harvest peat (thousands of tons) and, accordingly, the collection of peat per hectare (t/ha).

Step 2. For each group, we determine the amount of incremental product per hectare ( $\mathrm{t} / \mathrm{ha}$ ), which is formed relatively group with worse on natural quality of deposits. Naturally, the incremental product for this group is zero.

Step 3. Its necessity is dictated by the fact that, as noted above, production of incremental product is determined not only by the quality of the deposit, but also the technical level of production, which is a factor of entrepreneurial activity (capital). Individual level can vary from one side to another from the socio-normal, average. As a result, the group where individual level above, incremental product contains and that part which is obtained at the expense of the capital factor and it must objectively be attributed to entrepreneurs in the composition of the business income. Conversely, where the technical level of production is lower, then socio-normal, incremental product turns out to be low and in fact wounds rental income and thus overstates the entrepreneurial income. Therefore, the incremental value of product per 1 ha in each of the $i$-ies groups shall be adjusted on the $k_{i}$ factor, reflecting a deviation of individual production conditions in one direction or another from socio-normal, average conditions. We assume that the level of technical equipment is expressed by the organic structure of capital value, that can be represented in the naturalvalue form of capital endowment labour. For its calculation for each of the $i$-th group, along with data on the largest using mines take data on average annual largest used capital in thous. rub. (except for the passive part) and the number of employees (persons). Then from the relationship of these data (per one hectare of peat deposits) define an individual, for each of the $i$-th group, capital endowment level. Completing the third step in the calculation of the average, i.e. socio-normal for all groups, the level of labour capital endowment and already regarding on this average size determine for each of the $i$-th group correction factor $k_{i}$.

Step 4. Adjust in each of the $i$-th group values of incremental product by multiplying it on the corresponding correction factor this group $k_{i}$. Thereby, we cite the magnitude of incremental product in each of the groups of deposits, differing from each other by natural quality, to socio-normal, average production conditions. Thus, in those groups where conditions of production, the creation of which is a function of managing the peat deposits of the entrepreneurs, lower, then socio-normal levels, excluded natural rent should be set at 
a larger size than actually produced a product extension. In other groups where technical level of production is higher than the industry average, by contrast, the excluded portion of the profits in the form of natural rents should be reduced relatively incremental produced product, because it contains a portion of the surplus product, created at the expense of the entrepreneur's activities more effectively.

As you can see from the above, the proposed approach, as we see it, seems quite adequately reflects, firstly - the role of natural conditions in the production of incremental product, which is the substance of the rent. And, secondly, another part of the surplus product, which is the substance of business income, which may include, as the average profit so and excess profits that are attributable to the best individual production conditions compared with the average, socio-normal. But if, on the contrary, individual production conditions will be below the socially required level, the entrepreneurial profit after deducting rent naturally turns out to be even lower than the average profit. In this, actually, is the mechanism of intra-industry competition. And its implementation in the proposed approach - is a pledge that it would become a powerful factor in the attractiveness of peat mining for investors.

\section{Conclusion}

In conclusion we wants to note, that the practical feasibility of the proposed us approach requires addressing such important problem, as classification and distribution of all intended for the development of peat deposits into groups identical based on homogeneity of natural conditions and natural quality. As well as the problem of forms and methods of rent withdrawal by the State as the owner of mineral resources, taking into account and what each deposit is inherent in the objective life-cycle and its exploitation lead to exhaustion ("wear out") that essentially prejudge the law of diminishing profitability of entrails. In this regard, the rent rate withdrawals should be changed as the deterioration of the conditions using the peat deposit [16].

\section{References}

1. Energy 2020. A strategy for competitive, sustainable and secure energy. Communication from the Commission to the European Parliament, the Council, the European Economic and Social Committee and the Committee of the Regions. Brussels, 10.11.2010, URL: http://ec.europa.eu/energy/strategies/2010/2020_en.htm (accesssed 18.07.17).

2. G.A. Aleksandrov, T.B. Yakonovskaya, I.V. Vyakina, G.G. Skvortsova, Eur. Sci. Rev., 11-12, 96-100 (2014)

3. J. Korpi, Proceed. 13-th Int. Peat Cong., Tullamore, Ireland, 1, 120-122 (2008)

4. C.P Jones, Investments: Analysis and Management (John Wiley \& Sons Inc., 2012)

5. G.A. Alexandrov, I.V. Vyakina, G.G. Skvortsova, Act. Prob. Econ., 3:165, 415-428 (2015)

6. G. Alexandrov, I. Vyakina, G. Skvortsova, Asian Soc. Sci., 2:13, 10-20 (2017)

7. Ya.I. Yukhimov, Ya.Ya. Ivanova, Min. J., 9, 59-63 (2012)

8. G.E. Ortega, A. Pugachevsky, G. Walser, Mineral rights cadastre. Oil, Gas and Mining Policy Division of the World Bank (Washington, DC, USA, 2009)

9. V.V. Matyukha, Min. J., 7, 60-62 (2014) 
10. M. Nieć, K. Galos, K. Szamalek, Resources Policy, 42, 93-103 (2014)

11. J. Schumpeter, A History of Economic Analysis (Oxford University Press, 1954)

12. A. Smith, An Inquiry into the Nature and Causes of the Wealth of Nations (Colin Muir and David Widger, 2009)

13. K. Marx, Capital. Critique of political economy (Hamburg, 1885)

14. J.S. Mill, Principles of Political Economy (Oxford University Press, 2008)

15. N.V. Galtseva, O.A. Sharipova, I.S. Golubenko, I.N. Grigoryeva, Min. J., 3, 27-32 (2016)

16. G.A. Alexandrov, A.L. Yablonev, Min. J. (to be published) (2018) 
